\title{
All Quiet? The Memory and Historiography of the First World War in Poland
}

\author{
Maciej Maria GóRNY \\ Instytut Historii PAN im. Tadeusza Manteuffla, Warsaw
}

On 5th of August 2014 the Tower of London moat filled with exactly 888.246 ceramic poppies symbolizing soldiers of the British Commonwealth fallen in the Great War. Watched from the distance, they resembled a sea of blood pouring out from one of the Tower's windows. Everyday, short after sunset, a moving ceremony takes place there. A beefeater reads aloud data of 180 fallen soldiers, including their names, rank and military unit they served in. A guardsman accompanying him (or her) plays the trumpet, touched spectators contemplating the moment in silence, disturbed solely by the traffic sounds. This ceremony will repeat everyday till $11^{\text {th }}$ of November, when the poppies will be removed and sold for charity purpose.

A traveller from the other corner of the EU watching the Tower ceremony faces something he would most probably miss at home: firmly established memory culture of the First World War that is capable of connecting old rituals to the newish staging ideas, (while basing i?) based on convictions, symbols and images common for the vast majority of the country's population. For the British, the Great War is one of the most vital lieux de mémoire while for professional historians it still remains an issue disputable ${ }^{1}$. There are very few places in Eastern Europe that fall under a similar category, even on a smaller scale.

\section{Missing Memory}

There are some objective reasons to that asymmetry, next to obvious cultural differences. It would be extremely difficult, for example, to achieve British precision in the estimation of the numbers of killed, missed in action, mutilated or the prisoners of war in Eastern Europe. How about regions that had been battlefields not once but in three or four subsequent offensives and counteroffensives? Do civilian victims of the great operations fought by the German, Austro-Hungarian and Russian armies on the

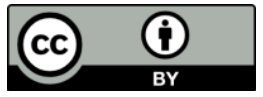

Article received at 11-3-2014 and accepted for publication at 12-13-2014.

1. With the approaching centennial of the Great War, memory of the conflict in Western Europe became topic to numerous publications that cannot be comprehensively dealt with within the scope of this article. Among the most informative and easily accessible are surely the sections of the Berlin-based 19141918.online encyclopedia devoted to the commemoration and afterlife of the First World War, authored by Elise Julien, Rémi DAlisson, Aaron COHEN, Laurence VAN YPERSELE, Silke FeHLEMANN and Patricia JALLAND (<http://encyclopedia.1914-1918-online.net>). A considerably shorter entry devoted to the memory of the war in East Central Europe (consisting, interestingly, of Poland, the Baltic states and Finland) rightly assesses that "Paradoxically, despite the significance of this conflict for the entire region's history, historiography has not paid much attention to the commemoration of the war until recent years" (Jussi Jalonen, Richter Klaus, Piotr Szlanta, Commemoration, Cult of the Fallen (East Central Europe), in: 1914-1918-online. International Encyclopedia of the First World War, ed. by Ute DANIEL, et alii, issued by Freie Universität Berlin, Berlin 2014-10-08. DOI: 10.15463/ie1418.10441, last modified: 2014-10-05.) Among the most recent publications on British memory culture see Ross J. WILSON, Cultural Heritage of the Great War, Farnham, Ashgate, 2013. 


\section{GÓRNY All Quiet?}

densely populated territory of central Poland count as well? How do you actually identify the nationality of the fallen imperial subjects? What was the identity of illiterate peasants who died for their tsar, emperor or king? And prisoners of war, refugees and expelled who died in camps in Siberia, Austria or Bohemia, (during escape) when escaping or upon their return home? What category of victims do they belong to?

The differences of memory cultures between Eastern and Western Europe are partly an effect of a striking misbalance of historical knowledge about the course of the war and its effects. Although collective memory and historiography are surely not the same, there is a connection between the two. The weakness of the memory in Eastern Europe is partly the cause and partly the effect of the long standing negligence on the part of indigenous historians. Therefore, without a closer look to the memory cultures of Eastern Europe, any report on the state of the art of the regional First World War studies would be incomplete.

We live in a time when the division of Europe into the capitalist modern West and communist backward East is becoming increasingly irrelevant. The Elbe River, a once obvious border, has grown less and less important in economy and politics. Our memory, the memory of cataclysms of the twentieth century in particular, is a stronghold of the old order. In this light, in the East (not without exceptions, though) the status of the First World War is in fact slightly different, less prominent, than in the West. Below I will try to address the following three issues: firstly, why is the war forgotten in this very part of the world?; secondly, are there any areas in this public amnesia in which the Great War plays a momentous role?; and thirdly, what scientific, political, and social effects can be caused by recent phenomena - especially the expected boom connected with the centenary of the conflict?

The insignificant presence of World War I in Eastern European communities' collective memory may come as a surprise, especially bearing in mind the physical consequences of these hostilities. The figures are really striking, even if we consider just the territory of Poland. More than four hundred thousand Poles in the military uniforms of three empires were killed, and over twice as many were injured. The oftencompulsory Russian evacuation in the summer of 1915 comprised nearly one million people, whose return stretched out until the mid-1920s. The destroyed cities and villages, material and cultural losses could be compared to those of the worst-affected land near the front line in Belgium and northern France. Small wonder - the battles on the Eastern Front were no less fierce and bloody than those on the Western Front, only that they were fought in larger areas. Due to the fact that it was a manoeuvre warfare, more arduous and also more dangerous - to both the soldiers and the civilians - than a position warfare.

There are a number of explanations, and each of them concerns not only Poland but also some other states in the region. In the East, great empires fought with each other; however, it was mainly representatives of smaller nations those who lost their lives. In spite of the fact that practically all nationalities remained loyal to the throne, none of them could imagine a potential victory of their state. On the contrary, enfeebling the ruling elites in order to win concessions from them to Poles, Czechs, Slovaks, Rumanians, Ukrainians, Belarusians, Lithuanians, Latvians, Estonians, Jews, Serbs, Croatians or Slovenians was in the interest of the majority. Their fighting spirit must have been mitigated by a feeling that fellow countrymen would most presumably fight and die in the uniforms of an enemy empire. When the war was over, that is to say, when the history of its memory and commemoration had begun, some events occurred that downgraded the previous four years almost completely. The emergence of new 
nation-states was a result not of the war, but of the defeat of empires. When the dust of battle settled, it turned out that it was not the majority, namely, combatants who fought for the Tsar or the Emperor, who were in possession of collective memory - but representatives of numerically marginal groups. The number of Polish legionaries, like Czechoslovak soldiers or Croatians fighting on the Allied side, never exceeded 1 per cent of the country's military personnel. Small wonder then, that the tale of war, which they had monopolised, did not become a common heritage. As a matter of fact, it was soon overshadowed by the memory of another war, whose consequences in this region were even more tragic. The year 1945 exacerbated the situation by connecting memory to the rigours of geopolitics, and - in Yugoslavia - to mandatory forgetting of the conflict, in which Croatians, Serbs, Slovenians and Bosnians dressed in Habsburg uniforms fought against Serbs. As it turned out later, making the First World War taboo in Yugoslavia seemed like a very reasonable idea. In the 1960s, when both historiography and pop culture rediscovered the Serbian Golgotha and made it a pillar of the independent, Serbian collective memory, the hitherto consistent structure of the multi-ethnic federation, began to break.

The weakness of memory of the Great War in the East has two sources. The first is an inability to relate with any side of the conflict, as most of the states there at the outset failed to survive until 1918. The second is a potentially toxic memory of the fratricidal conflict, or - in Serbia, Bosnia and Croatia - the conflict between nations inhabiting one state after 1918. However, there are no rules without exceptions. If we take a closer look at local communities and civic initiatives, the picture becomes quite complicated, and regional differences, which do not always respect present-day political borders, come to the fore.

These regionalisms have been justified by the material heritage. Yet, due to the turbulent decades after 1918 and especially 1939, many artefacts connected to the First World War disappeared or fell into oblivion. Warsaw, to take perhaps the most striking example, does not have a commemoration of the Great War. The only place that, albeit only partly, does justice to the soldiers of 1914-1918 is the Tomb of the Unknown Soldier. However, all of the dozen-or-so battles from that period that had been inscribed on memorial tablets refer to the minor battles fought by Polish Legions within the Austro-Hungarian army and the tiny group of Polish volunteers to the French army. Quite recently, Robert Blobaum, an American historian, expressed his hope that the $100^{\text {th }}$ anniversary would contribute to the reconstruction of the only Warsaw monument devoted to the sufferings of city's civilian population, the sculpture by Xawery Dunikowski. It had been erected in 1922 but removed temporarily in 1930, and finally destroyed in the Second World War. Reconstructed, it could be a hitherto missing symbol of the Polish World War experience. "There remains the monument of the desperate mother and her two hungry children which once stood prominently on Hoover Square - to my mind the most symbolic representation of everyday life in Warsaw during the First World War. The planned reconstruction and resurrection of that monument, originally announced in 2006, has been inexplicably delayed. I can imagine no better moment than the centennial of August 1914 for a ceremonial unveiling of that statue, not necessarily "in gratitude to America" (the inscription on the original statue), but in remembrance of a forgotten war and its horrific impact on the lives of the majority of city's non-combatants"2. Small wonder that Blobaum's hope remained

2. Robert Blobaum, "Warsaw's Forgotten War", in Remembrance and Solidarity. Studies in 20th Century European History, issue 2, March 2014, p. 205. 


\section{GÓRNY All Quiet?}

disappointed. Hoover Square has been reconstructed without the stone symbol of gratitude.

\section{Local Exceptions}

But outside big cities of Eastern Europe there are places that preserve the memory of the Great War. An ever-present feature of the landscape of East Germany (including the former East Prussia), Austria, the Czech Republic, Slovakia and Hungary is crosses and small monuments commemorating those who died in one or both world wars. In Poland we can come across them in Cieszyn Silesia, for example. Military cemeteries, especially the ones established by Austro-Hungarian military authorities during the war, constitute a special vestige. Several dozen of them are outstanding creations of the Slovak architect Dušan Jurkovič - fascinating both for their historical significance and for their artistic merit. In the area of the former Russian region of partition, and also in Ukraine, Belarus and Latvia, there are not as many symbols of affinity between local communities and casualties of the Great War and, more importantly, only very few people can read them. Sometimes local memory preserves scraps of information about the First World War, yet it associates it with the real war that followed. In fact, it is hard to find cities and towns here whose experiences between 1914 and 1918 were so dramatic that World War II could not blot out the memory of them. Consequently, exceptions become even more prominent. In the Galician towns of Gorlice and Przemyśl, World War I constituted the worst disaster in history. The battles of Riga, Belgrade, Warsaw, or Kaunas were merely a glimpse of the atrocities that followed.

As early as the 1980s, a grassroots social movement emerged for the protection of the heritage of the Great War, military cemeteries in particular. It developed during the following decade, as a renovation of necropolises in Slovakia and in Poland was initiated - often supported by Austrian institutions (chiefly the Austrian Black Cross). Recently, an informal network of Polish, Slovak, Austrian, Czech, and Hungarian associations have taken care of the cemeteries and propagated the knowledge of the First World War in the region. They shall have enough work to keep them busy: AustroHungarian architects, whose job was to blend the graveyards in with the submontane scenery, built many crosses and fences using wood, i.e. a material that is hardly permanent. Furthermore, in the 1920s, stealing lumber from cemeteries was extremely common. This phenomenon had the biggest impact in the former Russian region of partition, but ordinary citizens and then the nationalism of the new authorities left their imprint on military cemeteries in Galicia, Czechoslovakia and Yugoslavia, too. Many of the cemeteries which had not been destroyed were nationalised by the new national states. The procedure involved distorting the truth about the origin of the deceased. Multi-ethnic graveyards officially became the burial grounds of Polish legionaries or Latvian riflemen, although in some of them not even one representative of these formations had been buried ${ }^{3}$. Sometimes in - or next to - graves from the First World War, graves of victims of the following hecatomb appeared.

3. Jerzy Patosz, "The Military Cemetery as a Form of the Cult of the Fallen Soldier: The History of the Idea and Its Destruction on the Example of Austro-Hungarian Cemeteries in "Russian Poland", in Remembrance and Solidarity. Studies in the 20th Century European History, 2/March 2014, pp. 299-323. 


\section{Historiography}

The centenary of the Great War has enabled grassroots initiatives for heritage protection to come to prominence, to gain access to the media and regional education programmes, even though in most of Eastern Europe there were no official commemorations to the outbreak of the hostilities. It has also increased the (hitherto weak) interest of historians from Eastern Europe in the subject - partly due to external causes rather than an inner need: international projects need and actively seek Polish partners. Local topics and authors thus benefit from the widely acknowledged need to write a truly global war history, which cannot be achieved without the Eastern and the Balkan fronts ${ }^{4}$. This new approach can be traced in the monumental Cambridge history of the Great War with sections penned by American and German specialist in the history of Eastern Europe (notably Peter Gatrell and Christoph Mick) ${ }^{5}$. It is definitely too early to judge whether this transnational phenomenon translates into (the) a growing interest in the topic within the Polish historiography.

A slight rise in popularity of the First World War can be observed in Poland, the Czech Republic, Hungary, Russia and Romania; all the neighbours, however, are now outdistanced by Serbia, where Christopher Clark's well-known book about the causes of World War I has been discussed even more ferociously than in Germany. In Poland, two new syntheses of the First World War history appeared in 2014, after more than twenty years from the last volume penned by Janusz Pajewski ${ }^{6}$. The first, authored by Andrzej Chwalba, offers a traditional, well-informed narration of the military and diplomatic affairs accompanied by scant chapters devoted to the social and cultural history of the war. It concentrates on Western Europe, while short section on the end of the book gives a telegraphic report on the emerging and re-emerging states in East Central and Southeast Europe ${ }^{7}$. The second Polish synthesis, authored by Włodzimierz Borodziej and this author, concentrates on East Central and Southeast Europe solely, while devoting most of the interest to non-military issues, such as the social and cultural history of the region. It is organized along the division of the three types of wartime experience, into front, hinterland and occupation ${ }^{8}$. In Polish bookshops these two books compete with translated volumes ${ }^{9}$. Unfortunately, none of the path-breaking newer syntheses of the Great War can be found among those translations. The absence list is long and includes prominent authors. Neither Hew Strachan's classic volume ${ }^{10}$, nor the

4. Hew StRachan, “The First World War as a Global War", in First World War Studies, 1 (2010), 1, pp. 3-14.

5. Jay WinTER (ed.), The Cambridge History of the Great War, vol. 1-3, Cambridge, Cambridge University Press, 2014.

6. Janusz PAJEWSKI, Pierwsza wojna światowa, Warsaw, PWN, 1991.

7. Andrzej ChwalbA, Samobójstwo Europy. Wielka Wojna 1914-1918, Kraków, Wydawnictwo Literackie, 2014.

8. Włodzimierz BoRODZIEJ, Maciej GóRNY, Nasza wojna, vol. I, Imperia 1912-1916, Warsaw, WAB, 2014.

9. Barbara W. Tuchman, Sierpniowe salwy (transl. Maria \& Andrzej MichEJDA), Warsaw, WAB, 2014; TUCHMAN, Wyniosła wieża (transl. Janina ZAWADZKA), Warsaw, WAB, 2014; Theo ARONSON, Zwaśnieni monarchowie. Triumf $i$ tragedia europejskich monarchii $w$ latach 1910-1918 (transl. Aleksander GLONDYS), Kraków, Wydawnictwo Literackie, 2014; Peter HART, I wojna światowa. Historia Militarna (transl. Jan SZKUDLIŃSKI), Warsaw, Rebis, 2014.

10. Hew StRachan, The First World War, vol. I, To Arms, Oxford, Oxford University Press, 2001. 


\section{GÓRNY All Quiet?}

brilliant book by Jörn Leonhard (which devotes quite a few pages to the problems of East Central Europe) ${ }^{11}$ found their way into the Polish publication programmes. Alan Kramer and John Horne remain equally inaccessible to the Polish-reading audience ${ }^{12}$. This may, though not necessarily must, lead to certain blockades in the reception of new ideas and in their implementation onto the Polish or East Central European subject matter. Let us take a closer look on how recent trends in the Polish First World War research correspond to the general pattern of historiographical development.

Jay Winter and Antoine Prost identify three phases of the development of First World War historiography. In the first phase the diplomatic history dominated whereas military historians restricted their interest to generals and great battles. The absence of a common man, a poilu or a civilian was an Achilles' heel of that paradigm. This weakness was then recognized mostly by the Western European researchers influenced by Marxism. In their view, was played the main role was the fact that dominating in the field throughout the second half of the $20^{\text {th }}$ century, social processes, accommodation and resistance to the military discipline as well as changing moral norms of the European societies. The third turn in the First World War studies started in the 1990s. Without abandoning the social bias of the latter, it enriched the research perspective with cultural studies. Individual and group experience of the war belong to the typical topics of this research trend, along with cultures of memory, representations of the war and gender issues ${ }^{13}$. In practical terms, this development shifts historians' interests from the military to the civilians' matters. This, in turn, quasi naturally elevates the position and meaning of Eastern Europe for the new military history. Suffice it to remind that the main characteristics of the manoeuvre warfare on the Eastern and on the Balkan front that differed most from the Western front had been precisely constant proximity of military and civilian affairs. Contrary to mostly regular trench war, in the East soldiers met their civilian compatriots or the population of the enemy country on a daily basis. Some of the specific modes of contact between civilians and the military belong to the most promising fields of the Eastern Europe's First World War studies: occupation (of Poland, Lithuania, Latvia, Estonia, Belarus, Ukraine, Serbia and Romania), voluntary and forceful migrations as well as the phenomenon of violence which is inseparable from both aforementioned questions. Interestingly enough, traditional military history seems to be in decline in comparison with these rising topics. It is surely not an accident that one of the most interesting recent studies of this latter genre devotes more attention to the political and symbolic conflicts around the alleged desertions of Czech soldiers in the Habsburg army than the critical events on the battlefields of Galicia ${ }^{14}$.

There has been a great interest of the specialists in military occupations in the East that has been devoted - not without the influence of Vejas Gabriel Liulevicius'

11. Jörn LeONHARD, Die Büchse der Pandora. Geschichte des Ersten Weltkriegs, Munich, C. H. Beck, 2014.

12. Alan Kramer, Dynamic of Destruction: Culture and Mass Killing in the First World War, Oxford, Oxford University Press, 2007; idem \& John HoRne, German Atrocities, 1914: A History of Denial, New Haven, Yale University Press, 2001.

13. Jay WINTER \& Antoine PROST, The Great War in History: Debates and Controversies, 1914 to the Present, New York, Cambridge University Press, 2005, 13-27.

14. Richard LEIN, Pflichterfüllung oder Hochverrat? Die tschechischen Soldaten Österreichs-Ungarns im Ersten Weltkrieg, Viena, LIT-Verlag, 2011. 
seminal work - to the Ober Ost ${ }^{15}$. In many ways, this bias distorts the perspective, since Ober Ost by no means represented a norm. Suffice it to mention that, contrary to other occupied territories, Ober Ost retained strict military government up to 1918. In consequence, forced labor and lack of self-government remained characteristic for this region for the whole period of the war. German occupation of the so called Congress Kingdom (the Russian partition of Poland) was as different in nature from the semicolonial, militarist and brutal reign of Ludendorff over Lithuania, Belarus, parts of Latvia and Eastern Poland (that constituted Ober Ost's territory) as was the German occupation in Romania ${ }^{16}$. In Warsaw and in other regional centers there had been local political representation capable of influencing the policy of the German Generalgouvernement. Yet, interestingly, this fact has been largely neglected by historians up to the present. In recent works by Arkadiusz Stempin ${ }^{17}$ and Marta Polsakiewicz ${ }^{18}$ the consensual character of the German occupation is problematized and its liberal cultural policy rightly estimated. On the other hand, almost a year of Russian occupation of Eastern Galicia (from autumn 1914 to summer 1915) still awaits a comparable treatment. It is worth mentioning that more than a decade ago a monograph of Warsaw historian Włodzimierz Mędrzecki on the German military intervention in Ukraine in 1918 also analyzed another example of the negotiated occupational regime ${ }^{19}$.

Voluntary and forced migration, known as the Great retreat, had been common experience of various groups: Belarusians, Ukrainians, Russians, Jews, Poles, Germans, Lithuanians and Latvians. Perhaps the most striking feature of studies devoted to this phenomenon is separate treatment of individual nationalities, mostly but not exclusively done by scholars representing this particular nationality. Researchers dealing with the Jewish community do not bother to study similar war experiences of the Jews' neighbours. And vice-versa ${ }^{20}$. This ethnic segmentation is typical for Polish scholars in the field as well ${ }^{21}$. Interestingly enough, though rather unintentionally, this perspective dates back to the First World War itself. Already in 1914 an ethnicization of the refugee policy had been an issue. Suffice it to remind that the inefficient Russian authorities delegated the bulk of charity work to the organizations of ethnic or religious character.

15. Vejas Gabriel LiUleviCIUS, War Land on the Eastern Front: Culture, National Identity and German Occupation in World War I, Cambridge - New York, Cambridge University Press, 2000.

16. On the latter, see Lisa MAYERHOFER, Zwischen Freund und Feind - deutsche Besatzung in Rumänien 1916-1918, Munich, Martin Meidenbauer, 2010.

17. Arkadiusz StemPIN, Próba"moralnego podboju” Polski przez Cesarstwo Niemieckie w latach I wojny światowej, Warsaw, Neriton, 2013.

18. Marta POLSAKIEWICZ, "Spezifika deutscher Besatzungspolitik in Warschau 1914-1916", in Zeitschrift für Ostmitteleuropa-Forschung, 58 (2009), pp. 501-537.

19. Włodzimierz MĘDRZECKI, Niemiecka interwencja militarna na Ukrainie w 1918 roku, Warsaw, DiG, 2000.

20. For Ukraine see Yuriy I. MAKAR, Vid deportatsii do deportatsii. Suspilno-polytychne zhyttya (19151947), doslizhennya, spohady, dokumenty, vol. 1-3, Chernivci, Bukrek and ChNu, 2011.

21. Katarzyna SIERAKOwSKA, "Kobiety-uchodźcy z ziem polskich w czasie I wojny światowej" in Agnieszka CHLEbOWSKA and Katarzyna SIERAKOWSKA (eds.), Kobiety i procesy migracyjne Warsaw, Neriton, 2010, pp. 151-159. See also Mariusz KORZENIOWSKI, Marek MĄDZIK and Dariusz TARASIUK, Tułaczy los. Uchodźcy polscy $w$ imperium rosyjskim $w$ latach pierwszej wojny światowej, Lublin, Wydawnictwo Uniwersytetu Marii Curie-Skłodowskiej, 2007; Marek MĄDZIK, Polskie Towarzystwo Pomocy Ofiarom Wojny w Rosji w latach I wojny światowej, Lublin, Wydawnictwo Uniwersytetu Marii Curie-Skłodowskiej 2011. 


\section{GÓRNY All Quiet?}

In effect Russians were helping mostly Russians, Jewish help went to the Jews and Polish to the ethnic Poles ${ }^{22}$. Another interesting research question touches upon the refugees' return to their homes. Thanks to the effort of Peter Gatrell (but with significant contributions by Polish authors), the nationalist policy of the new Eastern European states has been studied relatively well ${ }^{23}$. Konrad Zieliński, probably the best Polish specialist in the wartime history of Poland's Jewish community, points to the connection between the Polish restrictions towards returning Jews and the big wave of Jewish emigration to the USA in early $1920 \mathrm{~s}^{24}$. The latter ended abruptly by mid-1920s, when the US-authorities restricted the immigration laws with the intention to decrease the number of Jewish immigrants. Though devoted not specifically to the First World War, another book by a Polish author should be mentioned in this context. Jan M. Piskorski's interpretation of Europe's 20th century forced migration has been translated into German ${ }^{25}$. At almost precisely the same time, a brilliant study by Philipp Ther, a German scholar at the university in Vienna devoted to a similar topic, appeared both in German and in Polish ${ }^{26}$. In both cases, however, the post-1939 expulsions and ethnic cleansing play a much more prominent role than the migrations of 1914-1918.

A common denominator of these two topics - forced migrations and military occupations - is violence. Some parts of East Central Europe seem especially prone to this research perspective. The Ukrainian territories remain in the center of historians' interest. Among a number of Polish studies in this field, Grzegorz Skrukwa's history of the Ukrainian 'national revolution' 1914-1921 is of particular value. The author devoted a great deal of attention to the phenomenon of uncontrolled violence as well as to the specific type of warlordism in post-1917 Ukraine. His general observations exceed the specific topic of his study, contributing to the general typology of postwar conflicts in Eastern Europe $^{27}$.

Another important chapter in the history of war-related violence concentrates on the Jewish community. This topic is by no means a novelty; as a matter of fact basic Polish contributions date back to 1980 s at least. Pogroms accompanying the following

22. Studies on Jewish refugees form the biggest part of this ethnic-specific genre, see i. e. Eric LOHR, "The Russian Army and the Jews: Mass Deportations, Hostages, and Violence during World War I", in The Russian Review, 60 (2001), 3, pp. 409-419; idem, Nationalizing the Russian Empire: The Campaign Against Enemy Aliens during World War I, Cambridge, Cambridge University Press, 2003; Marsha L. ROZENBLIT, Reconstructing a National Identity: The Jews of Habsburg Austria during World War I, Oxford, Oxford Univserity Press, 2001; Alexander V. PRUSIN, Nationalizing a Borderland: War, Ethnicity, and Anti-Jewish Violence in East Galicia, 1914-1920, Tuscaloosa, University of Alabama Press, 2005.

23. Nick BARON and Peter GAtrell (eds.), Homelands: War, Population and Statehood in Eastern Europe and Russia, 1918-1924, London, Anthem Press, 2004; Peter GATRELL, A Whole Empire Walking: Refugees in Russia during World War I, Bloomington, Indiana University Press, 2000 \& 2005.

24. Konrad ZIELIŃSKI, "Population Displacement and Citizenship in Poland, 1918-24" in BARON and GATRELL, Homelands..., pp. 98-118.

25. Jan M. PISKORSKI, Wygnańcy. Przesiedlenia i uchodźcy w dwudziestowiecznej Europie, Warsaw, Państwowy Instytut Wydawniczy, 2010; idem, Die Verjagten. Flucht und Vertreibung in Europa des 20. Jahrhunderts (transl. Peter Oliver LOEW), Munich, Siedler, 2013.

26. Philipp THER, Die dunkle Seite der Nationalstaaten. ,Ethnische Säuberungen 'im modernen Europa, Göttingen, Vandenhoeck \& Ruprecht, 2011; idem, Ciemna strona państw narodowych. Czystki etniczne w nowoczesnej Europie (transl. Tomasz GABIŚ), Poznań, Wydawnictwo Poznańskie, 2012.

27. Grzegorz SKRUKWA, Formacje wojskowe ukraińskiej “rewolucji narodowej” 1914-1921, Toruń, Adam Marszałek, 2008. 
wars in the former empires of Habsburg and Romanov had been analyzed by Jerzy Tomaszewski ${ }^{28}$. Later, a thorough history of the Jewish community in the immediate postwar years was studied by Piotr Wróbel, who continues his research on the topic to this day. Among the younger specialists, Konrad Zieliński excels in the study of PolishJewish relations ${ }^{29}$.

Apart from the aforementioned thematic triangle - occupation, forced migrations and violence - some individual research perspectives enrich the Polish history agenda. The memory of the war (or lack thereof) is recently gaining some interest, pointed out by the articles and conference papers of Marcin Jarząbek ${ }^{30}$. Marek Przeniosło specializes in peasant attitudes to the Polish irredentism in 1914-1918 ${ }^{31}$. Jerzy Z. Pająk published a regional account of the wartime experience in Austrian Galicia ${ }^{32}$. Tomasz Kargol touched upon an important and still largely ignored question of economic losses caused by war on the Polish territory ${ }^{33}$. The author of this study published a monograph devoted to Eastern European anthropology, geography, and psychology in the context of the Great $\mathrm{War}^{34}$. Piotr Szlanta studies political sympathies of the Polish population ${ }^{35}$. Ryszard Kaczmarek entered quite a new field in his work on the Polish soldiers serving in the German imperial army ${ }^{36}$.

28. Jerzy TOMASZEWSKI, "Lwów, 22 listopada 1918", in Przeglad Historyczny, LXXV (1984), 2, 279285; idem, "Pinsk. Saturday 5 April 1919”, in Polin. Studies in Polish Jewry, 1 (1986), 227-251.

29. Piotr J. WróBel, "Foreshadowing the Holocaust: The Wars of 1914-1921" and "Anti-Jewish Violence in Central and Eastern Europe", in Jochen BöHLER, Włodzimierz BoRODZIEJ, Joachim von PUTTKAME (eds.), Legacies of Violence: Eastern Europe's First World War, Munich, Oldenbourg Verlag, 2014, pp. 169-207; idem, "The Kaddish Years. Anti-Jewish Violence in East Central Europe, 1918-1921", in Jahrbuch des Simon-Dubnow-Instituts, 4 (2005), 211-236; K. ZIELIŃSKI, "The anti-semitic riots on the territories of the Kingdom of Poland at the beginning of independence”, in Studia Żydowskie, 3 (2013), 3, pp. 87-94; idem, Stosunki polsko-żydowskie na ziemiach Królestwa Polskiego w czasie pierwszej wojny światowej, Lublin, Wydawn. Uniwersytetu Marii Curie-Skłodowskiej, 2005.

30. Marcin JARZĄBEK, “Górnoślązacy żołnierze I wojny światowej. Rekonesans badawczy”, in Bernard LINEK, Sebastian RoSENBAUM and Kai STRUVE (eds.), Koniec starego świata - początek nowego. Społeczeństwo Górnego Śląska wobec pierwszej wojny światowej (1914-1918). Źródła i metody, conference papers, Opole 2013, pp. 26-35, as well as some other contributions to this conference volume.

31. Marek PrZeniosŁo, Chłopi Królestwa Polskiego w latach 1914-1918, Kielce, Wydawn. AkademiiŚwiętokrzyskiej, 2003; idem, "Postawy chłopów Królestwa Polskiego wobec okupanta niemieckiego i austriackiego (1914-1918)", in Daniel GRINBERG, Jan SNOPKO and Grzegorz ZACHIEWICZ (eds.), Lata Wielkiej Wojny. Dojrzewanie do niepodległości 1914-1918, Białystok, Wydawn. Uniwersytetu w Białymstoku, 2007, pp. 198-214.

32. Jerzy Z. PAJĄK, Od autonomii do niepodległości. Kształtowanie się postaw politycznych i narodowych społeczeństwa Galicji w warunkach Wielkiej Wojny 1914-1918, Kielce, Wydawn. Uniwersytetu Jana Kochanowskiego, 2012; idem, O rzad $i$ armię: Centralny Komitet Narodowy (1915-1917), Kielce, Akademii Świętokrzyskiej, 2003.

33. Tomasz KARGOL, Odbudowa Galicji ze zniszczeń wojennych w latach 1914-1918, Kraków, Towarzystwo Wydawnicze 'Historia Iagellonica', 2012.

34. Maciej GóRnY, Wielka Wojna profesorów. Nauki o człowieku (1912-1923), Warsaw, Instytut Historii PAN, 2014.

35. Piotr SzlantA, "Unter dem sinkenden Stern der Habsburger. Die Fronterfahrung polnischer k. u. k. Soldaten", in Bernhard BACHINGER and Wolfram DORNIK (eds.), Jenseits des Schützengrabens. Der erste Weltkrieg im Osten: Erfahrung - Wahrnehmung - Kontext, Innsbruck, Studien Verlag, 2013, pp. 139-156; idem, "Der Glaube an das bekannte Heute, der Glaube an das unsichere Morgen. Die Polen und der Beginn des Ersten Weltkriegs", in Jahrbücher für Gesichte Osteuropas, 3(2013), pp. 411-432.

36. Ryszard KACZMAREK, Polacy w armii kajzera, Kraków, Wydawnictwo Literackie, 2014. 


\section{GÓRNY All Quiet?}

At least a considerable part of these studies abandon the traditional ethnocentric perspective. As a matter of fact, many new topics cannot be analyzed adequately without a broader view of the region and beyond. International interest in First World War quasi enforces at least some activity on the side of the Polish researchers, be it only as contributors to international internet databases ${ }^{37}$. Although there are still many Polish authors for whom the First World war serves solely as a background of the Polish irredentist movement, they no longer set the tone. There seems to be some life in this particular branch of historical research, despite virtual absence of the Great War from the Polish collective memory.

\section{Conclusion}

Will this asymmetry between memory and history last? Will the growing historians' interest in the topic inspire mass media and influence the public or, rather, after a short mobilization in wake of the $100^{\text {th }}$ anniversary, it will decrease? In my opinion, it depends on the status of the First World War in prevailing national historical narratives. In Serbia or in Hungary the war is as a very important feature of them; elsewhere, as in Poland, it matters far less. Due to the fact that Poland's anniversaries calendar is filled with events, the renaissance of the subject in the public space this year lasted literally a few days, until August 1, that is, when discussion on the Warsaw Uprising of 1944 began anew.

Perhaps the Polish memory of the Great War might be rekindled by showing how strongly it is connected with events which have been important to local and national communities: the establishment or re-establishment of independence, the end of empires and the birth of the Europe of nations in which we have lived. How should it be done? By showing that there was practically no discontinuity between 1914 and 1920 and that the process included the entire region? It seems that a similar thought inspired the poet Kazimierz Przerwa-Tetmajer in the early 1920s, when he wrote: "The war was a womb from whence Poland came which we have now"38. It is worth thinking about it as our war, if only for that very reason.

37. International Encyclopedia of the First World War, <www.1914-1918-online.net>. Among the 70 authors there is one Polish contributor. On the internet sites devoted to the First World War see Aleksandra PAWLICZEK, "Memory in the Digital Age: First World War and Its Representation on the Web", in Remembrance and Solidarity. Studies in the 20th Century European History, 2/March 2014, 4771 .

38. Kazimierz PRZERWA-TetMAJER, Tradycja żolnierza polskiego, Warsaw, Wydaw. Red. 'Żołnierza Polskiego', 1920, p. 23. 